\title{
Deciphering the Detective and Feminist Elements in Dan Brown's, "the Da Vinci Code
}

\author{
Nehasri Ravishenbagam and Rohan Samuel. S \\ Department of English, SRM Institute of Science and Technology, Kattankulathur, India
}

\section{ABSTRACT}

This research work intends to decipher and shed light on the detective elements in the story of, "The Da Vinci Code" by the prolific writer, Dan Brown, and to prove that this novel abides by the rules of a Crime fiction genre. To attain this, our work is categorized into several parts for a better understanding. Also, here we chose to take a closer look at the theme of, Sexism that is sprinkled all over this novel in small doses. Sophie Neveu, one of the prominent figures along with other characters in the selected novel is proof that women are not inferior in any way as they are often portrayed by men. And, this part of our work deals with sexism and the taxonomy of each individual and delving deep into how they are the torch bearers of feminism and also how they are performing their role in proving that they are at times even more proficient than men.

\section{KEY WORDS: CRIME FICTION, DETECTIVE ELEMENTS, SEXISM, WOMEN, FEMINISM.}

\section{INTRODUCTION}

What Is Crime Fiction?: Crime Fiction as the name suggests, the stories in this said genre revolve around a crime scene that has occurred. The existing crime scene would most probably be a murder. With time, there arrives an amateur or a professional detective to investigate the murder case and towards the end of the story, it would be shaped as the criminal who was all the way long involved in that particular murder getting arrested by the cops or in some other cases the criminal would be put to death by the protagonist. Also, some Crime Fiction stories would have the possibility of having the protagonist as the main criminal and not as the detective of the story. Though a Crime Fiction story investigates a crime, involves an act of revenge, confronts secrets, corrects a wrong act, and so on, it also must concentrate on solving a complex puzzle that unties all the truths at the end of the story. The most-read genre of Crime Fiction can also be defined through other names such as Detective Fiction, Murder Mystery, etc. Hence, our research aims to decipher the detective elements present in the best-seller, "The Da Vinci

Biosc Biotech Res Comm P-ISSN: 0974-6455 E-ISSN: 2321-4007

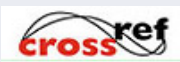

Identifiers and Pagination

Year: 2021 Vol: 14 No (8) Special Issue

Pages: $39-43$

This is an open access article under Creative

Commons License Attribn 4.0 Intl (CC-BY).

DOI: $h t t p: / / d x$.doi.org/10.21786/bbrc/14.8.9
Code" by Dan Brown that came out in the year, 2003. Alongside, we analyze sexism and how the characters in the novel are exposed to this concept.

About The Author: Daniel Gerhard Brown, best known for his thriller novels is an America-based author. His novels usually have a storyline that occurs over 24 hours with his recurring themes of Art, Cryptography, and some Conspiracy theories. An interesting fact is that his books have already been translated into 57 languages as of the year, 2012. Brown since his childhood has always had an interest in secrets and puzzles. He spent his childhood days working on some anagrams and crossword puzzles. These kinds of interests within him ever since his childhood are a major reason behind his thriller novels holding up a lot of secrets and complex puzzles in them.

The Da Vinci Code As A Crime Fiction Novel: The story begins at the Museum of Louvre wherein occurs the murder of the Curator, Jacques Saunière by an unidentified man. Eventually appears at the crime scene to investigate it is the story's protagonist, Robert Langdon, and the female lead and the granddaughter of the Curator, Sophie Neveu. They team up and discover clues from Leonardo Da Vinci's paintings leading to the ultimate discovery of a religious mystery that is about the Holy Grail guarded for almost 2000 years by a secret society by the name, "Priory of Sion" in which Saunière was an important member. The antagonist, Sir Leigh Teabing wants to find the Holy Grail and the secret of

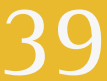


it to be exposed to the whole world. The story revolves around all these three main characters and their hunt for the Holy Grail.

The novel, The Da Vinci Code by, Dan Brown comes under the genre of Mystery in Crime Fiction in which the reader along with the protagonist has a zero-knowledge of what is about to happen in the next minute of the story. In the thrilling story of The Da Vinci Code, the reader is not even given a single piece of hint or information to guess the actual criminal. Resulting in, the reader experiencing an edge of seat experience as they travel along with the protagonist having a similar set of emotions that the protagonist undergoes throughout the story while trying to identify the criminal. As some of the basic elements of Crime Fiction are that the story that comes under this must consist of the character of a detective, some suspects, an antagonist, a crime scene, and a proper setting, the following work is to prove that the novel of The Da Vinci Code abides by all of these and by the significant characteristics of the said genre.

1. A story of Crime Fiction must have complex puzzles and must be difficult to solve.

At the initial stages of the novel when the murder of the curator of the Louvre Museum, Jacques Saunière is discovered, the protagonist Robert Langdon is asked to come over to the crime scene in the Grand Gallery by Bezu Fache who is the captain in the French national criminal-investigation Police bureau. That particular scene consists of a lot of unsolved puzzles that a common man would find hard to solve. As Robert Langdon was a Professor of Symbology, he uses his knowledge and tries to decode it. Langdon first finds out that the curator has framed his own body like a pentacle with his blood. Eventually, he decodes the last message written by the curator beside the place where he laid. The message said, "13-3-2-21-1-1-8-50, Draconian devil! Oh, lame saint! P.S. Find Robert Langdon” Sophie Neveu without a second thought found out that the numbers mentioned were the Fibonacci sequence. And, later on, Langdon decodes it to be the Curator's account number wherein he kept the safe-deposit box. The latter was then decoded to be, "Leonardo Da Vinci" and "Mona Lisa". After finding the painting of Mona Lisa, they find another anagram scrawled across the face of the painting, "SO DARK THE CON OF MAN.” Decoding the anagram was, "The Madonna of the Rocks" behind the painting is where they find a key with the initial of P.S. All of these are just a few instances that relate to one of the significant characteristics of how Crime Fiction should be. Sophie once states about the Curator, "He loved anything with multiple layers of meaning. Codes within codes." This is more likely to reflect on the story that the whole journey is to have a lot of twists and turns in its plot.

2. An innocent must be wrongly accused at the beginning of the investigation.

Robert Langdon is shown to be delivering a lecture in his introductory scene and is interrupted by a police officer while he was later that day in his hotel room. The French Official asked him for his assistance to investigate the murder of Jacques Saunière. A startled Langdon hurried with the Officer to the crime scene and little did he know that he is doubted to be the prime suspect of the murder of the Curator because the French Police officials get the information that the Curator and Langdon had arranged a meeting on the day before his murder. The officials think that they could extract the truth that Langdon killed the Curator and close the case. But, to their amusement Langdon only confesses to the Officials that the Curator did arrange a meeting with him and he failed to show up. Langdon has no idea of these accuses laid upon him and innocently tries to solve the codes that the Curator left behind. Even when Sophie asks him why were the two about to meet that night before of the Curator's death, Langdon seems to be truly perplexed and explains that, "His secretary set the meeting and didn't offer any specific reason, and I didn't ask. I assumed he'd heard I would be lecturing on the pagan iconography of French cathedrals, was interested in the topic, and thought it would be fun to meet for drinks after the talk."

3. The incomplete acts of the dim-witted Police and the protagonist must perform better than the Police.

BezuFache, captain of Direction Centrale Police Judiciaire, and Jérôme Collet, a lieutenant in France's Direction Central Police Judiciaire (DCPJ) are the two main Police Officials involved in investigating the murder of the Curator of the Louvre Museum. As Fache finds that Langdon's name was mentioned by the Curator before his death, he fixes in his mind that Langdon was the culprit and only focuses on arresting him. It is Langdon and Sophie, who finds out that the murder of the Curator has more hidden secrets than one could ever think and they try their best to unfold the mystery behind his death.

4. The Crime must be filled with complexities and must be committed by a criminal who is a worthy opponent to the protagonist.

The clever antagonist of The Da Vinci Code is, the Teacher. The identity of the Teacher was not even known to Silas who was performing all the tasks that the Teacher asked him to perform through the phone and in one instance Silas says that "My Teacher is very wise" Indeed he is. The disguised character named Teacher was none but, Langdon's dearest friend, Sir Leigh Teabing. He is truly a Criminal mastermind who executes his plans wisely and is a tough competitor to the protagonist actually. Sir Teabing's whole intention is to bring out the longkept secret of the Holy Grail by the Priory of Sion. To achieve his goal, he brilliantly performs the murders of the members of the Priory of Sion by issuing orders to his slave, Silas.

The abovementioned are the major characteristics of how a perfect Crime fiction work should be written. The instances that occur in The Da Vinci Code undoubtedly get in sync with all the characteristics of a crime fiction work. The following part of the research work is an 
analysis dealt with how the theme of Sexism is treated in the novel, The Da Vinci Code.

Sexism And Feminism: Sexism is the classification of genders and having a stereotype that must be honored by people of either gender. According to a sexist point, women must forever be playing second fiddle to men and they won't have the liberty to think on their own. Sexism aims to maintain a power difference between the two genders. However, the general consensus is that men are solely responsible for the sexist laws being implemented on women. But women can actually be the allies of their own oppression and if they let the systematic oppression take control and make peace with the fact that they cannot do anything of their own, then they are also in agreement with the sexism and discrimination against them.

Feminists may argue on how sexism is not allowing them have any sort of freedom but men are facing the same prejudice enforced against them too. Men are naturally expected to stay strong no matter the situation. They don't have the liberty to even cry, vent out emotions. Phrases like "Man up" "Be a man" "Real men" encourage men to stay strong in the face of adversity. Just the thought of not allowing men to even express a form of natural emotion is scary. Thus, sexism haunts masses of both sexes and none are excluded. "The Da Vinci Code," has its own share of incidents that involves sexism and other stereotypes. Sophie Neveu, Robert Langdon, and, Sir Leigh Teabing all have a hard time because of the gender roles bestowed upon them.

Sexism is the gender power differences and beliefs that create nothing but unrest and disrupts harmony. Contrary to the popular belief, this affects both men and women. This is evident in the novel, "The Da Vinci Code" where men and women are struggling to abide by the stereotypes they fall into. Feminism is simply a movement by some activists to promote equality among the masses. According to the stereotype, women are relegated to kitchens and they are nothing but slaves cooking for their husbands. Leaving their homes and standing out for themselves is not an option for them. They had no control over their marriage and it was up to the men who decided that. This is why most of the girls got married as soon as they were 15 . The most common assumption about women is that they are not as proficient and efficient as men and we can witness this many instances involving many characters in the novel.

Sophie Neveu: The female lead of Brown's novel, "The Da Vinci Code" is none other than a 30-year-old intelligent, self-made, and strong woman by the name, Sophie Neveu. She holds her position as a Cryptographer under the French National Police. This character serves as an example of how Brown has portrayed women and their must-needed equality in this particular novel. Sophie was raised by her grandfather, Jacques Saunière as her parents died in a car accident while she was at a very young age. Ever since a child, Sophie was interested in solving puzzles, codes, etc. and she was indirectly trained to solve those by her grandfather who raised her. Her grandfather was a genius just like her. She is the person who is present side by side in aiding Robert Langdon in deciphering various puzzles they encounter along the way. Though Langdon and Sir Teabing were portrayed to be super brains in the novel, the brain of Sophie was way smarter than theirs. But as she is a woman, automatically she is subjected to sexism by her friends, Langdon and Sir Teabing. They try to limit her to the role of an assistant who is fit only for obeying the master and not capable of thinking on their own.

"You're saying you can read this text?" Teabing exclaimed.

"Quite easily," Sophie chimed, obviously enjoying herself now.

"My grandfather taught me this language when I was only six years old. I'm fluent." (308)

Through this particular incident, we could undoubtedly witness the absolute shock of Sir Teabing and Sophie proved their view towards her as an inferior person wrong. This also shows how the theme of sexism is so hard-wired into the minds of men that they would even accept failure rather than asking for the aid of women. Also, through this very incident it is evident that Jacques Saunière has always had a huge amount of trust in Sophie and on her ability more than he trusted anyone around him. As she says that she has known this language since she was a kid, it seems to be obvious that Saunière has trained Sophie all her life just for this very moment.

Sophie could surely be described as a strong and determined woman. When she heard about the murder of her very own grandfather, she could have exposed her emotional side and could have become weak due to his loss like any other woman would have done. Sophie expresses her grief stating, "He raised me like his own daughter."Despite that, she also chose to showcase the other stronger side of her even though she underwent a lot of pain deep inside. She kept aside her emotional side and stood up for her grandfather and was ready to face any kind of hurdles that would stop her from finding the criminal.

Brown has strongly portrayed her character as an embodiment of determination, self-confidence, courage, and self-reliant woman. Sophie during her graduation period once comes home to her grandfather during her spring-break only to witness a horrifying scene in which her grandfather was involved. He was performing a sex ritual called, "Heiros Gamos". A terrified Sophie leaves the place without even a second thought and gets settled with some of her friends in a flat and she never did speak to him then after. Through this leading powerful woman character of Brown, all the single women out in the world are truly inspired to fight for their lives without being dependent on anyone at any cause. 
Also, there occurs a scene in which Bezu Fache, who doesn't like a woman taking up the lead in a group of Men mentions Sophie as a "Female Cryptologist" which is quite patronizing. But, despite all these sexism implied talks on her, Sophie keeps performing her duties very well. And even mention, at the beginning of the play when she and Landon are outnumbered and cornered by the Police in the museum, she uses her ability to come up with solutions quickly and they flee successfully. She constantly uses her wit to distract the Police from their trial many times. Hence, the character of Sophie Neveu proves that men are also at times not capable of making quick decisions in adverse situations and that it is a woman who helps them out of their hard times.

Sister Sandrine Biel: Sister Biel is the nun who is in charge of keeping the church of Saint-Sulpice up and running. She is no stranger to misogyny and discrimination in her life. The church she is working with has made her unsettled countless times with their views on how women should be treated. Other women working in the service of the church were forced to lie down on the hard ground. On the other hand, men who did the same work in the church had the advantage as they slept on straw mats. To add more misery she is ultimately killed by Silas. Silas and Sister are both believers of the Catholic Church, but their views differ totally. Silas is known to believe that women are inferior to men in every single aspect of life and Sister Sandrine is another casualty from the female side who lay down their life looking forward to a world that is without any prejudices aimed towards women.

"As Sister Sandrine fell, her last feeling was an overwhelming sense of foreboding." (141)

These lines show the amount of fear and anxiety she experienced while she was about to die in the hands of the violent murderer, Silas. Sister Sandrine wanted nothing more than equality and that Women should be treated the same way as men would be, from the eyes of the church. But the end result was nothing but the murder from a person who had strong opinions about women. Silas had a violent history with women dating back to his childhood days, where he beat up two girls and almost killed them.

Marie Chauvel: Chauvel was the caretaker of the Rosslyn Chapel and she was also the loving grandmother of Sophie. Ever since Sophie's parents met their fatal accident, she has been in hiding. She organizes secret meetings with her husband and how to keep their grandchildren safe because of their true identity.

"Jacques and I saw each other only very infrequently," (449)

Marie Chauvel is proof that, women don't need another man to care for them and that they are independent to safeguard themselves. She is able to break the shackles that chain women to a general conception of how they can't get by without the aid of men.
Robert Langdon: Langdon is the protagonist and one can even say he is the center focus of, "The Da Vinci Code" as he is a genius when it comes to solving complex puzzles left by the Curator. But not all are what it seems. His brain is hard-wired to be superior to women just like most men out there. There is a stereotype which goes "Men should be all-knowing" and they should never seek help from a woman. We can see throughout the novel just after the introduction of Sophie, Langdon has a hard time living up to the expectations assigned to a man. He is seen fleeing from the Police officials at the beginning of the novel. After getting cornered by the officials, it is a woman who helps him escape the police and this occur a couple of times. Langdon is also very reluctant when it comes to asking for help from Sophie whenever he can't solve a piece of a puzzle. This brings into light how men are stereotyped to treat women.

Silas: Silas is in command of the anonymous antagonist of the novel, the Teacher. He is also another victim who fall prey to sexism. Ever since his childhood, he has been exposed to women's abuse. In his home, life was not a bed of roses with his father constantly berating his mother. This finally prompts Silas to flee his home and live on the streets briefly. The streets made him into a monster, a hostile person towards women. Silas even got into a fight with a girl and almost beat her to death. The same instance happened again when a girl tried to snatch the lunch from Silas. After he grows up, his views on women grew stronger. He despised their very sight and wanted to delegate them to the depths of society. So when he meets Sister Sandrine he kills her without any second thoughts.

\section{CONCLUSION}

The fact that Crime fiction is a genre read by lots of people for its thrilling nature can never be denied. Dan Brown despite giving out a novel that had a lot of controversies to it also gave out the best thriller story that one would be reading with an edge-of-the-seat experience. It undoubtedly abides by the major features of how a proper crime fiction novel should be presented. And, Brown never let his women characters get portrayed as weak or subtle ones rather gave strong rules and equal status as men. Though women in the novel were victims of men's domination, they were strong enough to showcase their talents and performing better than the male characters. Sexism is just a belief that one sex is superior to or more valuable than another sex and it is high time that we all make sure both genders are treated with equality and have a world, free from gender inequality.

\section{REFERENCES}

danbrown.fandom.com/wiki/Sophie_Neveu

en.wikipedia.org/wiki/Sexism

files.hostgator.co.in/hostgator253199/file/

thedavincicode-danbrown.pdf

open.lib.umn.edu/sociology/chapter/11-2-feminismand-sexism/\#: :text=Feminism\%20and\%20sexism\%20 
are $\% 20$ generally,inequality $\% 20$ between $\% 20$ men $\% 20$ and\%20women.

saylordotorg.github.io/text_social-problems-continuityand-change/s07-02-feminism-and-sexism.html theconversation.com/global/topics/crime-fiction-8171 villains.fandom.com/wiki/Sir_Leigh_Teabing www.britannica.com/art/crime-fiction www.britannica.com/topic/feminism www.britannica.com/topic/sexism www.coe.int/en/web/human-rights-channel/stopsexism

www.coursehero.com/lit/The-Da-Vinci-Code/characteranalysis/

www.forbes.com/sites/kathycaprino/2017/03/08/whatis-feminism-and-why-do-so-many-women-and-menhate-it/?sh=2080d9487e8e

www.gender.cawater-info.net/knowledge_base/ rubricator/feminism_e.htm

www.google.com/search? q=crime+fiction+characterst icsetrlz=1C1RXQR_enIN929IN929ctoq=crime+fiction+ charactersticsctaqs $=$ chrome.0.69i59j0i13j0i390.5976j 1 j9ctsourceid=chromettie $=$ UTF-8

www.gradesaver.com/the-da-vinci-code/study-guide/ character-list

www.huffpost.com/entry/the-difference-betweenfe_b_5826636

www.nytimes.com/2018/08/19/business/sexismwomen-birthplace-workplace.html

www.profwritingacademy.com/why-we-love-crimefiction

www.shmoop.com/study-guides/literature/the-da-vincicode/summary

www.sparknotes.com/lit/davincicode/summary/

www.stcloudstate.edu/womenscenter/issues/sexismfeminism.asp $\mathrm{x}$ 